\title{
TUBB3 Gene
}

National Cancer Institute

\section{Source}

National Cancer Institute. TUBB3 Gene. NCI Thesaurus. Code C104242.

This gene is involved in microtubule function and structure. 